\title{
Effects of diesel exposure on lung function and inflammation biomarkers from airway and peripheral blood of healthy volunteers in a chamber study
}

Yiyi $\mathrm{Xu}^{1^{*}}$, Lars Barregard ${ }^{2}$, Jörn Nielsen ${ }^{3}$, Anders Gudmundsson ${ }^{4}$, Aneta Wierzbicka ${ }^{4}$, Anna Axmon ${ }^{3}$, Bo AG Jönsson ${ }^{1}$, Monica Kåredal ${ }^{3}$ and Maria Albin ${ }^{1}$

\begin{abstract}
Background: Exposure to diesel exhaust causes inflammatory responses. Previous controlled exposure studies at a concentration of $300 \mathrm{mg} / \mathrm{m}^{3}$ of diesel exhaust particles mainly lasted for $1 \mathrm{~h}$. We prolonged the exposure period and investigated how quickly diesel exhaust can induce respiratory and systemic effects.

Methods: Eighteen healthy volunteers were exposed twice to diluted diesel exhaust $\left(\mathrm{PM}_{1} \sim 300 \mu \mathrm{g} / \mathrm{m}^{3}\right.$ ) and twice to filtered air $\left(\mathrm{PM}_{1} \sim 2 \mu \mathrm{g} / \mathrm{m}^{3}\right)$ for $3 \mathrm{~h}$, seated, in a chamber with a double-blind set-up. Immediately before and after exposure, we performed a medical examination, spirometry, rhinometry, nasal lavage and blood sampling. Nasal lavage and blood samples were collected again $20 \mathrm{~h}$ post-exposure. Symptom scores and peak expiratory flow (PEF) were assessed before exposure, and at 15, 75, and 135 min of exposure.

Results: Self-rated throat irritation was higher during diesel exhaust than filtered air exposure. Clinical signs of irritation in the upper airways were also significantly more common after diesel exhaust exposure (odds ratio=3.2, $p<0.01)$. PEF increased during filtered air, but decreased during diesel exhaust exposure, with a statistically significant difference at $75 \mathrm{~min}(+4 \mathrm{~L} / \mathrm{min}$ vs. $-10 \mathrm{~L} / \mathrm{min}, \mathrm{p}=0.005)$. Monocyte and total leukocyte counts in peripheral blood were higher after exposure to diesel exhaust than filtered air $20 \mathrm{~h}$ post-exposure, and a trend $(p=0.07)$ towards increased serum IL-6 concentrations was also observed $20 \mathrm{~h}$ post-exposure.
\end{abstract}

Conclusions: Diesel exhaust induced acute adverse effects such as symptoms and signs of irritation, decreased PEF, inflammatory markers in healthy volunteers. The effects were first seen at $75 \mathrm{~min}$ of exposure.

Keywords: Diesel exhaust, Chamber experiment, Lung function, Biomarkers, Respiratory inflammation

\section{Background}

The adverse health effects of particulate air pollution are well documented [1-5], and urban outdoor air pollution was estimated to cause 1.34 million premature deaths worldwide in 2008, an increase of 16\% from 2004 [6]. Diesel exhaust (DE) emissions constitute, according to estimates from the USA, $4-16 \%$ of the total particulate matter (PM) in non-urban and urban areas [7,8]. People working around diesel equipment or living close to major

\footnotetext{
* Correspondence: yiyi.xu@med.lu.se

'Division of Occupational and Environmental Medicine, Lund University, SE 221-85 Lund, Sweden

Full list of author information is available at the end of the article
}

roadways are more likely to have irritant respiratory symptoms and reduced baseline pulmonary function $[9,10]$, and to develop respiratory disease including allergy [11], chronic obstructive pulmonary disease [12,13], and lung cancer [14-16].

Epidemiological studies have shown associations between $\mathrm{DE}$ and respiratory diseases, but the underlying mechanisms are still not fully understood and the exposure needs to be better characterized to improve the basis for risk assessment in occupational and environmental settings. Part of this knowledge gap was filled by a series of controlled human diesel exhaust exposure studies carried out in Umeå, Sweden. They monitored exposure, and

\section{Biomed Central}

(c) 2013 Xu et al.; licensee BioMed Central Ltd. This is an open access article distributed under the terms of the Creative Commons Attribution License (http://creativecommons.org/licenses/by/2.0), which permits unrestricted use, distribution, and reproduction in any medium, provided the original work is properly cited. 
investigated the mechanisms behind the observed effects. Healthy and asthmatic volunteers were exposed in an exposure chamber to either DE concentrations of $300 \mu \mathrm{g} / \mathrm{m}^{3}$

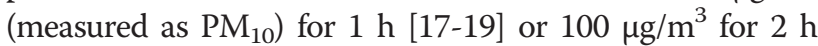
$[20,21]$. The results demonstrated that DE exposure caused inflammatory responses at $6 \mathrm{~h}$ and $18 \mathrm{~h}$. This was indicated by increased cell counts (neutrophils, B lymphocytes and eosinophils) and concentrations of fibronectin and methyl histamine in airway lining fluid, as well as increase neutrophils and mast cells, up-regulation of endothelial adhesion molecules and interleukins in bronchial biopsies [17-19,22]. In one experiment, this airway inflammation was also followed by an increase of neutrophils and platelets in peripheral blood [19].

Additionally, a DE-induced bronchoconstrictive response (increased airway resistance and specific airway resistance) was observed as measured by computerized whole body plethysmography $[20,23,24]$. However, no significant change was detected with conventional pulmonary function tests (dynamic spirometry and peak expiratory flow) $[19,25]$.

The Umeå studies have provided extensive knowledge on the respiratory effects of moderate DE exposure. However, the absence of lung function changes in conventional tests in most of the Umeå studies may be due to the relatively short exposure time and follow-up time. In the present investigation, which is a part of the DINO study "Health Effects of Combined Exposure to Diesel and Noise", we prolonged the exposure time to $3 \mathrm{~h}$ and monitored symptoms and peak expiratory flow (PEF) over the whole exposure period. The aim was to find potential relationships between exposure and effects, and to monitor how quickly such changes would develop.

\section{Materials and methods Subjects}

Eighteen healthy, non-smoking volunteers $(9$ males and 9 females) with a mean age of 51 (range 40-66) years were recruited. Inclusion criteria were no symptoms or diagnosis of asthma, normal chest auscultation, lung function and a negative skin prick test to a standard panel of aeroallergens for atopy. The study was approved by the Regional Ethical Review Board, and all subjects provided written consent.

\section{Exposure protocol}

Each subject underwent four different exposure scenarios at rest (seated quietly): (1) Reference exposure: low DE concentration (measured as mass concentration of particles with an aerodynamic diameter less than $1 \mu \mathrm{m}, \mathrm{PM}_{1} \sim 2 \mu \mathrm{g} / \mathrm{m}^{3}$ ) and low traffic noise (46 dB(A)); (2) Diesel exposure: high DE concentration $\left(\mathrm{PM}_{1} \sim 300 \mu \mathrm{g} / \mathrm{m}^{3}\right)$ and low traffic noise; (3) Noise exposure: low DE concentration and high traffic noise (75 dB(A)); and (4) Diesel and noise exposure: high $\mathrm{DE}$ concentration and high traffic noise. Exposure lasted for $3 \mathrm{~h}$ and took place in a specially built exposure chamber
(22 $\mathrm{m}^{2}$, suitable for 3 persons simultaneously) on different occasions in a randomized sequence, at least one week apart. The study design was double-blind, however, the difference between high and low traffic noise was easily noticed by study subjects and the physician.

In this paper, the reference exposure and the noise exposure were merged and renamed "filtered air" (FA) exposure, while the diesel exposure and the diesel and noise exposure were merged and renamed "diesel exhaust" (DE) exposure, since no interactions were found between DE and noise in any marker of respiratory effects (see Statistical analysis section).

The DE was generated from a passenger car (Volkswagen Passat TDI, $-98,1900 \mathrm{~cm}^{3}, 81 \mathrm{~kW}$ ) running in idle mode. Swedish Environmental Class 1 diesel fuel with a sulfur content less than $10 \mathrm{ppm}$ was used. Dilution was controlled to supply the desired concentration of particles to the chamber for the different exposure scenarios. Details of diesel aerosol generation, as well as DE characteristics in both particle and gas phase are reported elsewhere [26]. Traffic noise recorded at a street crossing was played from two loudspeakers reproducing each channel in a stereo recording. The noise had a continuous, natural change of noise level. The temperature and the relative humidity in the chamber were maintained at $23^{\circ} \mathrm{C}$ and between $30 \%$ and $40 \%$, respectively. Characteristics of DE and FA exposures are presented in Table 1.

\section{Self-reported symptoms and medical examinations}

The questions about symptoms of upper airways, including runny nose, nasal congestion, throat irritation and chest tightness, were rated on a visual analogue scale (VAS) (range 0 to 100 millimeter) before exposure, and at 15, 75 and 135 min into exposure during each exposure session. The VAS is most appropriate at repeated measurement within subjects as it has the sensitivity required to measure minute changes [27]. Signs of nose and throat irritation (redness/secretion/swelling) were recorded (normal/slight/moderate/pronounced), and auscultation of lungs was performed in a medical examination before and after exposure by the same

Table 1 Exposure details during DE and FA exposures

\begin{tabular}{lcc}
\hline & DE exposure & FA exposure \\
\hline $\mathrm{PM}_{1}$ mass concentration $\left(\mu \mathrm{g} / \mathrm{m}^{3}\right)$ & $276 \pm 27$ & $2 \pm 2$ \\
Number concentration $\left(\right.$ particles $\left./ \mathrm{cm}^{3}\right)$ & $388000 \pm 48000$ & $14 \pm 16$ \\
$\mathrm{NO}(\mathrm{ppm})$ & $9.8 \pm 1.0$ & $0.003 \pm 0.001$ \\
$\mathrm{NO}_{2}(\mathrm{ppm})$ & $1.3 \pm 0.4$ & $0.002 \pm 0.001$ \\
$\mathrm{CO}_{2}(\mathrm{ppm})$ & $1945 \pm 125$ & $947 \pm 67$ \\
Formaldehyde $\left(\mu \mathrm{g} / \mathrm{m}^{3}\right)$ & $400 \pm 97$ & 7.5 \\
Temperature $\left({ }^{\circ} \mathrm{C}\right)$ & $22.7 \pm 0.7$ & $22.7 \pm 0.8$ \\
\hline
\end{tabular}

Values are mean \pm standard deviation (SD).

$D E$, diesel exhaust; $F A$, filtered air. 
physician. For scheduling of examinations and samplings see Table 2.

\section{Lung function and nasal patency}

PEF was measured in two ways: (1) PEF data output from a Mini-Wright Peak Flow Meter (MWPFM) with a measuring range of $60-800 \mathrm{~L} / \mathrm{min}$, which was measured four times (three recordings each time) in each exposure session: before exposure and at 15, 75 and 135 min into exposure; (2) PEF data output from a computerized spirometer (SPIRARE 3, DIAGNOSTICA, Oslo, Norway), which was measured only before and after exposure (three recordings each time).

Rhinometry and spirometry (a minimum of three recordings for each outcome) were performed before and after exposure: forced vital capacity (FVC) and forced expiratory volume in one second $\left(\mathrm{FEV}_{1}\right)$ were measured according to the European Respiratory Society guidelines [28], using the computerized spirometer. The minimal cross-sectional area between $0-22 \mathrm{~mm}\left(\mathrm{MCA}_{1}\right)$ and between $22-54 \mathrm{~mm}\left(\mathrm{MCA}_{2}\right)$ into the nasal opening, and the volume of the nasal cavity between these distances (Volume ${ }_{1}$ and Volume ${ }_{2}$ ) were determined using acoustic rhinometry (RhinoScan v. 2.5, Interacoustics A/S, Assens, Denmark) [29]. The "best" results at each time point from PEF, spirometry and acoustic rhinometry measurements were included in the statistical analysis.

\section{Nasal lavage}

Nasal lavage was performed in this study since it has been proposed as a noninvasive method to detect upper airway inflammation of air pollutants [30,31]. We conducted nasal lavage before exposure, after exposure, and at $20 \mathrm{~h}$ post-exposure (range $18-22 \mathrm{~h}$ ), with minor modifications as described by Benson et al. [32]. Briefly, 18 $\mathrm{ml} 37^{\circ} \mathrm{C} 0.9 \% \mathrm{NaCl}$ solution was instilled with a syringe into one nostril until the liquid appeared in the opposite one. The liquid was sucked back and instilled again. The procedure was repeated three times in each nostril. The lavage liquid was immediately chilled and the cells were separated by centrifugation (Centrifuge 5702R, Eppendorf
AG, Hamburg, Germany). The supernatant was separated from the pellet and stored at $-80^{\circ} \mathrm{C}$ until analysis of inflammatory markers.

\section{Inflammatory markers in blood and nasal lavage}

Peripheral blood samples (before exposure, after exposure, $20 \mathrm{~h}$ post-exposure) were analyzed for total and differential leukocyte cell counts (Sysmex XE-1800i). Plasma fibrinogen (Sysmex CA-7000) and C reactive protein (CRP, Cobas c501) concentrations were determined.

The serum concentrations of interleukin-6 (IL-6) and IL-8, and the nasal lavage concentrations of IL-6, IL-8, intercellular adhesion molecule-1 (ICAM-1) and tumor necrosis factor- $\alpha$ (TNF- $\alpha)$ were analyzed by multiplexed magnetic bead-based immunoassays on a Luminex platform (Bio-Plex 200, Bio-Rad Life Science, Hercules, CA).

Clara cell protein $(\mathrm{CC} 16)$ and surfactant protein D (SP-D) in serum were analyzed using commercial ELISA kits from Biovendor (BioVendor Laboratory Medicine, Inc., Brno, Czech Republic), according to the protocols supplied by the manufacturer. The imprecision, expressed as coefficient of variation, was $13 \%$ for $\mathrm{CC} 16$ and $12 \%$ for SP-D, as calculated from duplicate analyses.

\section{Statistical analysis}

Absolute changes from baseline were calculated for each individual and each exposure scenario to reduce the influence of inter-individual variation for the data from self-rated symptoms, lung function, biomarkers in blood and nasal lavage. Then the four exposure scenarios were merged into two, as explained above, since the effect of noise did not modify the effect of DE in any of the markers ( $>0.06$ for all); the variation of the mean $\mathrm{PM}_{1}$ mass concentrations between all DE exposures (i.e. the diesel exposures and the diesel and noise exposures) from the mean value of $276 \mu \mathrm{g} / \mathrm{m}^{3}$ (Table 1) was on average smaller than $6.5 \%$. The changes in the selected outcome measures at DE exposure vs. changes at FA exposure were analyzed with repeated-measures analysis of variance using a linear model type of the generalized estimating equation in SPSS 18.0 (SPSS Inc., Chicago,

Table 2 Scheduling and time point of different examinations, blood and nasal lavage samplings

\begin{tabular}{|c|c|c|c|c|c|c|}
\hline \multirow[t]{2}{*}{ Item } & \multirow{2}{*}{$\begin{array}{l}\text { Before exposure } \\
\text { (outside chamber) }\end{array}$} & \multicolumn{3}{|c|}{ During exposure (in chamber) } & \multirow{2}{*}{$\begin{array}{l}\text { After exposure } \\
\text { (outside chamber) }\end{array}$} & \multirow{2}{*}{$\begin{array}{l}20 \mathrm{~h} \text { post-exposure } \\
\text { (outside chamber) }\end{array}$} \\
\hline & & $15 \mathrm{~min}$ & $75 \mathrm{~min}$ & $135 \mathrm{~min}$ & & \\
\hline Self-rating symptoms & $\times(7: 40)$ & $\times(9: 45)$ & $\times(10: 45)$ & $\times(11: 45)$ & & \\
\hline Medical examination & $\times(7: 00)$ & & & & $\times(13: 10)$ & \\
\hline Peak expiratory flow & $\times(7: 40)$ & $\times(9: 45)$ & $\times(10: 45)$ & $\times(11: 45)$ & & \\
\hline Rhinometry & $\times(8: 30 \sim 9: 00)$ & & & & $\times(13: 20 \sim 13: 50)$ & \\
\hline Spirometry & $\times(8: 30 \sim 9: 00)$ & & & & $\times(13: 20 \sim 13: 50)$ & \\
\hline Blood samples & $\times(8: 30 \sim 9: 00)$ & & & & $\times(13: 20 \sim 13: 50)$ & $\times(7: 00 \sim 8: 30)$ \\
\hline Nasal lavage & $\times(8: 30 \sim 9: 00)$ & & & & $\times(13: 20 \sim 13: 50)$ & $\times(7: 00 \sim 8: 30)$ \\
\hline
\end{tabular}


IL, USA). Subject identification, the four initial exposure scenarios, and the time point of measurements were used to indicate the repeated measurements. Exposure sequence was not included in the final models since inclusion of the exposure sequence did not change the results.

The data from the medical examination was transformed to binary variables. If signs (redness/secretion/swelling of nose, throat, and sound of lung and heart auscultation) after exposure became worse than before exposure (from normal to slight, and so on), we recorded it as "getting worse", otherwise "no change". Any "getting worse" sign of nose and throat, or sound of lungs represented a corresponding positive finding of upper-airway irritation or lung signs. A binary logistic model type of generalized estimating equation was used to estimate the odds ratios.

Statistical significance refers to $\mathrm{p}<0.05$ (two-tailed). However, multiple comparisons were performed for self-rated symptoms (three times), PEF from MWPFM (three times), and inflammatory markers in blood and nasal lavage (two times). For those comparisons, statistical significance refers to $\mathrm{p}<0.017$ and $\mathrm{p}<0.025$, respectively, according to the Bonferroni correction.

\section{Results}

\section{Symptoms and Signs}

Scores of self-rated symptoms are presented in Table 3. Subjects reported a mild but progressive irritation in the throat during DE exposure, the increment on the VAS scale was 3.75 in DE exposure versus -1.53 in FA exposure $(\mathrm{p}=0.016)$ at $135 \mathrm{~min}$. No significant differences between exposures were detected in self-rated nose or chest symptoms.

Irritation in upper airways (nose and throat) was found in the physical examination. Exposure to DE increased the odds ratio (OR) of signs in the upper-airways $(\mathrm{OR}=3.2,95 \%$ CI 1.9-11.0). No change was found in lung sounds (data not shown).

\section{Lung function}

Similar PEF values at baseline were obtained with the MWPFM and the spirometer for both FA and DE exposure (Table 4). However, after 15 min of exposure, PEF decreased during DE exposure but increased during FA exposure, and this pattern lasted throughout the whole exposure period. The difference between PEF changes in DE and FA was $14 \mathrm{~L} / \mathrm{min}$ at $75 \mathrm{~min}$ of exposure (MWPFM, $\mathrm{p}=0.005$ ), 12 $\mathrm{L} / \mathrm{min}$ at $135 \mathrm{~min}$ of exposure (MWPFM, $\mathrm{p}=0.020$ ) and $10 \mathrm{~L} / \mathrm{min}$ after exposure (spirometer, $\mathrm{p}=0.078$ ) (Table 4).

The changes in spirometry $\left(\mathrm{FEV}_{1}, \mathrm{FVC}\right)$ and rhinometry results were small and similar after both DE and FA exposure (Table 5).

\section{Inflammatory markers}

There was a significantly greater increment of total leukocytes in blood at $20 \mathrm{~h}$ post-exposure following DE exposure compared to FA exposure (Table 6, $\mathrm{p}=0.007$ ), including a significantly higher increment of monocyte counts $(\mathrm{p}=0.017)$. A trend towards an increase in monocyte counts between DE exposure and FA exposure was suggested also immediately after exposure $(p=0.04)$. No such patterns were discerned for neutrophils, eosinophils or lymphocytes.

Data on other inflammatory markers in serum and nasal lavage are shown in Table 7. We only found a significant difference between $\mathrm{CC} 16$ changes in DE and FA exposure. A slight increase in CC16 was observed immediately after DE exposure and returned to baseline at $20 \mathrm{~h}$ post-exposure for DE exposure, while it increased at $20 \mathrm{~h}$ post-exposure of FA exposure $(\mathrm{p}=0.016)$. A trend towards a greater increment of serum IL-6 for DE exposure than FA exposure was suggested at $20 \mathrm{~h}$ post-exposure $(\mathrm{p}=0.066)$. However, CRP tended to decrease more rapidly after exposure to DE than after FA $(\mathrm{p}=0.034)$.

Table 3 Effects of FA exposure and DE exposure on self-rated symptoms

\begin{tabular}{|c|c|c|c|c|c|c|c|}
\hline & Before exposure & 15 min exposure & 75 min exposure & 135 min exposure & $\Delta 15 \min ^{\mathrm{a}}$ & $\Delta 75 \min ^{a}$ & $\Delta 135 \min ^{\mathrm{a}}$ \\
\hline \multicolumn{8}{|l|}{ FA exposure } \\
\hline Runny nose & $1.39 \pm 7.83$ & $0.08 \pm 0.5$ & $0.14 \pm 0.83$ & $0.00 \pm 0.00$ & $-1.31 \pm 7.86$ & $-1.25 \pm 7.88$ & $-1.39 \pm 7.83$ \\
\hline Nasal congestion & $1.69 \pm 7.99$ & $0.53 \pm 1.18$ & $0.61 \pm 1.87$ & $0.36 \pm 1.36$ & $-1.17 \pm 8.12$ & $-1.08 \pm 8.21$ & $-1.33 \pm 8.11$ \\
\hline Throat irritation & $1.66 \pm 7.46$ & $1.00 \pm 5.01$ & $0.11 \pm 0.46$ & $0.08 \pm 0.50$ & $-0.61 \pm 8.64$ & $-1.50 \pm 7.03$ & $-1.53 \pm 7.36$ \\
\hline Chest tightness & $--^{*}$ & $--^{*}$ & $--^{*}$ & $0.14 \pm 0.83$ & $--^{*}$ & $--^{*}$ & $0.14 \pm 0.83$ \\
\hline \multicolumn{8}{|l|}{$D E$ exposure } \\
\hline Runny nose & $2.86 \pm 10.91$ & $1.97 \pm 10.09$ & $1.44 \pm 7.66$ & $1.69 \pm 8.34$ & $-0.89 \pm 3.44$ & $-1.42 \pm 4.86$ & $-1.17 \pm 4.31$ \\
\hline Nasal congestion & $3.03 \pm 10.55$ & $1.72 \pm 7.52$ & $2.69 \pm 8.08$ & $3.53 \pm 9.32$ & $-1.31 \pm 4.33$ & $-0.33 \pm 8.10$ & $0.50 \pm 6.98$ \\
\hline Throat irritation & $2.31 \pm 6.96$ & $1.06 \pm 2.27$ & $4.00 \pm 8.64$ & $6.06 \pm 12.11$ & $-1.25 \pm 6.21$ & $1.69 \pm 10.32$ & $3.75 \pm 12.11^{\#}$ \\
\hline Chest tightness & $0.28 \pm 1.67$ & $0.17 \pm 0.74$ & $0.17 \pm 0.74$ & $0.56 \pm 2.29$ & $-0.11 \pm 1.51$ & $-0.11 \pm 1.85$ & $0.28 \pm 2.88$ \\
\hline
\end{tabular}

Values are mean \pm standard deviation (SD) using a visual analog scale.

$D E$, diesel exhaust; $F A$, filtered air.

${ }^{\mathrm{a}} \Delta 15 \mathrm{~min}=15 \mathrm{~min}$ of exposure - before exposure; $\Delta 75 \mathrm{~min}=75 \mathrm{~min}$ of exposure - before exposure; $\Delta 135 \mathrm{~min}=135 \mathrm{~min}$ of exposure - before exposure.

${ }^{*}$ No symptoms were reported. ${ }^{\mathrm{P}}<0.017$ for DE exposure vs. FA exposure. 
Table 4 Effects of FA exposure and DE exposure on PEF as measured using a MWPFM and a SPIRARE spirometer

\begin{tabular}{|c|c|c|c|c|c|c|c|c|c|}
\hline & $\begin{array}{c}\text { Before } \\
\text { exposure }\end{array}$ & $\begin{array}{c}15 \text { min } \\
\text { exposure }\end{array}$ & $\begin{array}{c}75 \text { min } \\
\text { exposure }\end{array}$ & $\begin{array}{c}135 \text { min } \\
\text { exposure }\end{array}$ & $\begin{array}{c}\text { After } \\
\text { exposure }\end{array}$ & $\begin{array}{l}\Delta 15 \\
\min ^{\mathrm{a}}\end{array}$ & $\begin{array}{l}\Delta 75 \\
\min ^{\mathrm{a}}\end{array}$ & $\begin{array}{l}\Delta 135 \\
\min ^{\mathrm{a}}\end{array}$ & $\begin{array}{c}\Delta \text { after } \\
\text { exosure }^{\text {a }}\end{array}$ \\
\hline \multicolumn{10}{|l|}{ FA exposure } \\
\hline$\overline{P E F}(L / m i n)$ from MWPFM & $530 \pm 73$ & $533 \pm 73$ & $534 \pm 73$ & $538 \pm 75$ & $--^{*}$ & $3 \pm 25$ & $4 \pm 26$ & $8 \pm 31$ & $--^{*}$ \\
\hline PEF ( $L / m i n)$ from spirometer & $524 \pm 88$ & $--^{*}$ & $--^{*}$ & $--^{*}$ & $531 \pm 90$ & $--^{*}$ & $--^{*}$ & $--^{*}$ & $8 \pm 27$ \\
\hline \multicolumn{10}{|l|}{ DE exposure } \\
\hline PEF (L/min) from MWPFM & $537 \pm 74$ & $531 \pm 75$ & $528 \pm 78$ & $534 \pm 81$ & $--^{*}$ & $-6 \pm 22$ & $-10 \pm 22^{\#}$ & $-4 \pm 18$ & $--^{*}$ \\
\hline PEF $(L / m i n)$ from spirometer & $530 \pm 93$ & $--^{*}$ & $--^{*}$ & $--^{*}$ & $527 \pm 89$ & $--^{*}$ & $--^{*}$ & $--^{*}$ & $-3 \pm 24$ \\
\hline
\end{tabular}

Values are mean \pm standard deviation (SD).

$D E$, diesel exhaust; $F A$, filtered air; PEF, peak expiratory flow; MWPFM, Mini-Wright Peak Flow Meter.

${ }^{\mathrm{a}} \Delta 15 \mathrm{~min}=15 \mathrm{~min}$ of exposure - before exposure; $\Delta 75 \mathrm{~min}=75 \mathrm{~min}$ of exposure - before exposure; $\Delta 135 \mathrm{~min}=135 \mathrm{~min}$ of exposure - before exposure;

$\Delta$ after exposure $=$ after exposure - before exposure.

*No PEF was recorded. ${ }^{\# P}<0.017$ for DE exposure vs. FA exposure.

\section{Discussion}

This study was extracted from DINO project, the overall aim of which was to evaluate the combined effect of $\mathrm{DE}$ and traffic noise on human physiological response (including also cardiovascular responses such as heart rate variability). Although effects of traffic noise on airways have not been documented, we still initially included traffic noise in the analysis, to see if it modified the reported or observed airway effects of DE. However, no such modifying effect was found in any markers of respiratory response. Moreover, the generation of $\mathrm{DE}$ was highly reproducible between the sessions. Thus, for optimal statistical power, we merged the four exposures into two: exposure or no exposure to DE.
The concentration of DE in this study was nearly $300 \mu \mathrm{g} / \mathrm{m}^{3}$, and such levels may occur at rush hours in large city centers. We found divergent trends in PEF changes during DE and FA exposure, and a significant DE-associated PEF decrease at $75 \mathrm{~min}$ in healthy subjects. Self-reported symptoms and the physical examination indicated irritation of the upper airways. The increase in peripheral leukocyte counts suggests a mild systemic inflammatory response, supported also by a tendency towards an increase in serum IL-6.

To the best of our knowledge, this is the first study that shows an effect on PEF in healthy subjects. DE induced a slight but consistent reduction in PEF that was significantly different from FA exposure at $75 \mathrm{~min}$. Thereafter

Table 5 Effects of FA exposure and DE exposure on spirometry (FEV $1, F V C)$ and rhinometry $\left(\mathrm{MCA}_{1}, \mathrm{MCA}_{2}\right.$, Volume $_{1}$, Volume $_{2}$ )

\begin{tabular}{|c|c|c|c|c|}
\hline & & Before exposure & After exposure & $\Delta$ after exposure ${ }^{a}$ \\
\hline \multicolumn{5}{|c|}{ Spirometry } \\
\hline \multirow[t]{2}{*}{$\mathrm{FEV}_{1}$} & FA exposure & $3.23 \pm 0.57$ & $3.26 \pm 0.58$ & $0.02 \pm 0.13$ \\
\hline & DE exposure & $3.23 \pm 0.60$ & $3.26 \pm 0.59$ & $0.03 \pm 0.08$ \\
\hline \multirow[t]{2}{*}{ FVC } & FA exposure & $4.12 \pm 0.71$ & $4.14 \pm 0.70$ & $0.02 \pm 0.16$ \\
\hline & DE exposure & $4.13 \pm 0.72$ & $4.17 \pm 0.72$ & $0.04 \pm 0.10$ \\
\hline \multicolumn{5}{|c|}{ Rhinometry } \\
\hline \multirow[t]{2}{*}{$\mathrm{MCA}_{1}$} & FA exposure & $1.12 \pm 0.28$ & $1.13 \pm 0.23$ & $0.01 \pm 0.18$ \\
\hline & DE exposure & $1.08 \pm 0.24$ & $1.13 \pm 0.24$ & $0.05 \pm 0.16$ \\
\hline \multirow[t]{2}{*}{$\mathrm{MCA}_{2}$} & FA exposure & $0.95 \pm 0.23$ & $1.06 \pm 0.25$ & $0.11 \pm 0.19$ \\
\hline & DE exposure & $0.94 \pm 0.20$ & $1.03 \pm 0.31$ & $0.10 \pm 0.23$ \\
\hline \multirow[t]{2}{*}{ Volume$_{1}$} & FA exposure & $4.06 \pm 0.75$ & $4.07 \pm 0.67$ & $0.01 \pm 0.26$ \\
\hline & DE exposure & $4.05 \pm 0.72$ & $4.10 \pm 0.69$ & $0.05 \pm 0.21$ \\
\hline \multirow[t]{2}{*}{ Volume $_{2}$} & FA exposure & $6.90 \pm 1.56$ & $8.16 \pm 1.59$ & $1.26 \pm 1.74$ \\
\hline & DE exposure & $6.51 \pm 1.19$ & $7.82 \pm 1.93$ & $1.32 \pm 1.58$ \\
\hline
\end{tabular}

Values are mean \pm standard deviation (SD).

$D E$, diesel exhaust; $F A$, filtered air; $F E V_{1}$, forced expiratory volume in one second; $F V C$, forced vital capacity; $M C A_{1}$, minimal cross-sectional area between 0-22 mm; $M C A_{2}$, minimal cross-sectional area between $22-45 \mathrm{~mm}$.

${ }^{\mathrm{a}} \Delta$ after exposure $=$ after exposure - before exposure. 
Table 6 Effects of FA exposure and DE exposure on cell count in peripheral blood

\begin{tabular}{|c|c|c|c|c|c|c|c|}
\hline \multirow[t]{2}{*}{ Cell type } & \multicolumn{5}{|c|}{ Cell count $\left(\times 10^{9} / L\right)$} & \multicolumn{2}{|c|}{$\begin{array}{c}\text { P-values for } \\
\text { DE exposure vs. FA exposure }\end{array}$} \\
\hline & $\begin{array}{l}\text { Before } \\
\text { exposure }\end{array}$ & $\begin{array}{c}\text { After } \\
\text { exposure }\end{array}$ & $\begin{array}{c}20 \mathrm{~h} \\
\text { post-exposure }\end{array}$ & $\begin{array}{c}\Delta \text { after } \\
\text { exposure }^{\text {a }}\end{array}$ & $\begin{array}{c}\Delta 20 \mathrm{~h} \\
\text { post-exposure }^{\mathrm{a}}\end{array}$ & $\begin{array}{c}\Delta \text { after } \\
\text { exposure }^{a}\end{array}$ & $\begin{array}{c}\Delta 20 \mathrm{~h} \\
\text { post-exposure }\end{array}$ \\
\hline \multicolumn{8}{|l|}{ FA exposure } \\
\hline Leukocytes & $5.45 \pm 1.36$ & $5.72 \pm 1.34$ & $5.17 \pm 1.17$ & $0.27 \pm 0.53$ & $-0.28 \pm 1.02$ & - & - \\
\hline Neutrophils & $3.02 \pm 1.15$ & $2.99 \pm 1.03$ & $2.64 \pm 0.75$ & $-0.04 \pm 0.31$ & $-0.38 \pm 0.99$ & - & - \\
\hline Eosinophils & $0.19 \pm 0.09$ & $0.20 \pm 0.11$ & $0.21 \pm 0.11$ & $0.01 \pm 0.06$ & $0.02 \pm 0.06$ & - & - \\
\hline Lymphocytes & $1.69 \pm 0.49$ & $2.02 \pm 0.64$ & $1.83 \pm 0.53$ & $0.33 \pm 0.32$ & $0.14 \pm 0.30$ & - & - \\
\hline Monocytes & $0.49 \pm 0.13$ & $0.48 \pm 0.15$ & $0.44 \pm 0.12$ & $-0.01 \pm 0.13$ & $-0.05 \pm 0.11$ & - & - \\
\hline \multicolumn{8}{|l|}{$D E$ exposure } \\
\hline Leukocytes & $5.29 \pm 1.00$ & $5.60 \pm 0.98$ & $5.45 \pm 1.37$ & $0.31 \pm 0.55$ & $0.16 \pm 1.01$ & 0.725 & 0.007 \\
\hline Neutrophils & $3.00 \pm 0.81$ & $2.91 \pm 0.63$ & $2.89 \pm 1.04$ & $-0.09 \pm 44$ & $-0.11 \pm 0.93$ & 0.474 & 0.139 \\
\hline Eosinophils & $0.19 \pm 0.12$ & $0.20 \pm 0.13$ & $0.22 \pm 0.13$ & $0.01 \pm 0.06$ & $0.03 \pm 0.07$ & 0.847 & 0.431 \\
\hline Lymphocytes & $1.59 \pm 0.48$ & $1.94 \pm 0.59$ & $1.82 \pm 0.64$ & $0.35 \pm 0.24$ & $0.23 \pm 0.35$ & 0.651 & 0.264 \\
\hline Monocytes & $0.47 \pm 0.11$ & $0.51 \pm 0.10$ & $0.48 \pm 0.13$ & $0.04 \pm 0.11$ & $0.01 \pm 0.10$ & 0.042 & 0.017 \\
\hline
\end{tabular}

Values are mean \pm standard deviation $(\mathrm{SD})$.

$D E$, diesel exhaust; $F A$, filtered air.

${ }^{\mathrm{a}} \Delta$ after exposure $=$ after exposure - before exposure; $\Delta 20 \mathrm{~h}$ post-exposure $=20 \mathrm{~h}$ post-exposure - before exposure

differences were still suggested at $135 \mathrm{~min}$ and after exposure, approaching significance. Our interpretation is that DE caused a transient lung function change with rapid recovery. PEF was seldom measured at DE exposure in healthy volunteers, but in asthmatics exposed to $\mathrm{DE}$ $\left(\mathrm{PM}_{10} 100 \mu \mathrm{g} / \mathrm{m}^{3}\right)$ for $2 \mathrm{~h}$, there was a non-significant trend towards a decreased PEF immediately after exposure [33]. Similar to other studies [20,34], we performed spirometry before and after exposures and failed to find significant difference in $\mathrm{FEV}_{1}$ changes, although we used a longer exposure time $(3 \mathrm{~h})$. This also reflected that the time points of monitoring may be important. In this study, there was a 50 min delay between end of exposure and spirometry, which may allow the lung function to recover. Moreover, the subjects of this study were older (mean age about 50 years) than in other studies.

The small but significant PEF changes in healthy subjects may imply that occupational DE limit values should be reconsidered. DE is quite common in occupational settings, and some studies have indicated adverse effects on lung function at long-term occupational exposure to DE in combination with dust $[10,35]$. The current American Conference of Governmental Industrial Hygienists (ACGIH) Threshold Limit Values (TLVs) for respirable particulates and $\mathrm{NO}_{2}$ are $3 \mathrm{mg} / \mathrm{m}^{3}$ and $3 \mathrm{ppm}$ as 8 -hour time-weighted averages (TWAs), respectively [36]. However, the present study indicates that substantially lower exposures ( $\mathrm{PM}_{1}$ level of $300 \mu \mathrm{g} / \mathrm{m}^{3}$ and $\mathrm{NO}_{2}$ of $1.3 \mathrm{ppm}$ ) to $\mathrm{DE}$ for only three hours will cause a transient effect on lung function.
As in previous studies [23,37], self-reported throat and eye irritation [26] increased during DE exposure, in agreement with objective signs at the physical examination. The emission of aldehydes is the most likely cause in the present study. A Swedish study found an increase in nasal irritation and lower respiratory tract symptoms at an average exposure of $260 \mu \mathrm{g} / \mathrm{m}^{3}$ of formaldehyde [38]. Our exposure level of formaldehyde, about $400 \mu \mathrm{g} / \mathrm{m}^{3}$, was higher than in these reports, and DE also contains other aldehydes such as acrolein that may cause such irritant symptoms.

In the present study, we used nasal lavage for measurement of the acute cytokines (IL-6, IL-8, TNF- $\alpha$, ICAM-1) to define the timing of inflammatory response in the nasal cavity instead of the more invasive bronchoalveolar lavage and bronchoscopy techniques. However, such repeated sampling of airway fluid could have the drawback of washout effect $[30,39]$, resulting in lower concentration of biomarkers in subsequent lavages and then diminishing real differences between DE and FA exposures. The only finding in nasal lavage in this study was a slight increase (not statistically significant) of IL-6 after DE exposure at $20 \mathrm{~h}$ post-exposure. Other cytokines (IL-8, TNF- $\alpha$, ICAM-1), on the contrary, remained unchanged. Nasal lavage has not been widely investigated in chamber studies of DE exposure, Blomberg et al. [40] only found an increase in ascorbic acid concentration in nasal lavage after diesel exposure $\left(1 \mathrm{~h}, \mathrm{PM} 300 \mu \mathrm{g} / \mathrm{m}^{3}\right)$. In other in vivo studies, intranasal challenge with allergen $+\mathrm{DE}$ in atopic subjects was found to increase IgE, IL-4 and histamine 
Table 7 Effects of FA exposure and DE exposure on inflammatory markers

\begin{tabular}{|c|c|c|c|c|c|c|c|}
\hline \multirow[t]{2}{*}{$\begin{array}{l}\text { Inflammatory } \\
\text { markers }\end{array}$} & \multicolumn{5}{|c|}{ Concentration of markers } & \multicolumn{2}{|c|}{$\begin{array}{c}\text { P-values for } \\
\text { DE exposure vs. FA exposure }\end{array}$} \\
\hline & $\begin{array}{l}\text { Before } \\
\text { exposure }\end{array}$ & $\begin{array}{c}\text { After } \\
\text { exposure }\end{array}$ & $\begin{array}{c}20 \mathrm{~h} \\
\text { post-exposure }\end{array}$ & $\begin{array}{c}\Delta \text { after } \\
\text { exposure }^{\text {a }}\end{array}$ & $\begin{array}{c}\Delta 20 \mathrm{~h} \\
\text { post-exposure }^{\mathrm{a}}\end{array}$ & $\begin{array}{c}\Delta \text { after } \\
\text { exposure }^{\mathrm{a}}\end{array}$ & $\begin{array}{c}\Delta 20 \mathrm{~h} \\
\text { post-exposure }^{\mathrm{a}}\end{array}$ \\
\hline \multicolumn{8}{|l|}{ FA exposure } \\
\hline Serum IL-6 (pg/ml) & $1.73 \pm 0.98$ & $1.69 \pm 1.13$ & $1.60 \pm 1.33$ & $-0.04 \pm 0.56$ & $-0.13 \pm 0.90$ & - & - \\
\hline Serum IL-8 (pg/ml) & $5.00 \pm 3.28$ & $4.91 \pm 3.26$ & $5.46 \pm 4.35$ & $-0.09 \pm 1.33$ & $0.46 \pm 2.48$ & - & - \\
\hline $\mathrm{NL}$ IL-6 (pg/ml) & $0.97 \pm 1.01$ & $0.94 \pm 0.86$ & $0.85 \pm 0.68$ & $-0.03 \pm 0.93$ & $-0.11 \pm 0.81$ & - & - \\
\hline $\mathrm{NL}$ IL-8 (pg/ml) & $67.0 \pm 73.3$ & $48.5 \pm 50.5$ & $49.9 \pm 66.6$ & $-18.6 \pm 71.5$ & $-17.1 \pm 49.4$ & - & - \\
\hline NL TNF-a(pg/ml) & $0.95 \pm 0.77$ & $0.84 \pm 0.14$ & $1.03 \pm 0.88$ & $-0.10 \pm 0.79$ & $0.08 \pm 1.19$ & - & - \\
\hline NL ICAM-1 (pg/ml) & $76.8 \pm 87.1$ & $76.6 \pm 101$ & $62.0 \pm 73.9$ & $-0.15 \pm 114$ & $-14.7 \pm 64.0$ & - & - \\
\hline CRP $(\mathrm{mg} / \mathrm{l})$ & $1.6 \pm 1.6$ & $1.5 \pm 1.7$ & $1.3 \pm 1.2$ & $-0.03 \pm 0.23$ & $-0.27 \pm 0.54$ & - & - \\
\hline Fibrinogen (g/l) & $2.9 \pm 0.5$ & $2.9 \pm 0.5$ & $3.1 \pm 0.6$ & $0.12 \pm 0.72$ & $0.24 \pm 0.66$ & - & - \\
\hline CC16 $(\mu \mathrm{g} / \mathrm{l})$ & $5.93 \pm 1.98$ & $5.84 \pm 2.20$ & $6.73 \pm 2.38$ & $-0.08 \pm 0.99$ & $0.61 \pm 1.56$ & - & - \\
\hline SP-D ( $\mu \mathrm{g} / \mathrm{l})$ & $66.9 \pm 34.0$ & $66.7 \pm 35.0$ & $70.8 \pm 36.1$ & $-0.21 \pm 9.42$ & $3.90 \pm 9.81$ & - & - \\
\hline \multicolumn{8}{|l|}{$D E$ exposure } \\
\hline Serum IL-6 (pg/ml) & $1.80 \pm 1.35$ & $1.64 \pm 1.14$ & $1.92 \pm 1.56$ & $-0.16 \pm 0.64$ & $0.12 \pm 0.78$ & 0.413 & 0.066 \\
\hline Serum IL-8 (pg/ml) & $5.10 \pm 3.62$ & $4.85 \pm 3.79$ & $5.59 \pm 3.74$ & $-0.25 \pm 1.90$ & $0.49 \pm 1.82$ & 0.666 & 0.940 \\
\hline $\mathrm{NL}$ IL-6 (pg/ml) & $1.32 \pm 2.03$ & $1.29 \pm 2.08$ & $2.01 \pm 5.04$ & $-0.03 \pm 2.35$ & $0.70 \pm 4.64$ & 0.983 & 0.247 \\
\hline $\mathrm{NL} \| \mathrm{L}-8$ (pg/ml) & $71.3 \pm 71.7$ & $63.9 \pm 97.8$ & $48.6 \pm 46.7$ & $-7.40 \pm 98.4$ & $-22.7 \pm 48.1$ & 0.483 & 0.597 \\
\hline NL TNF-a (pg/ml) & $0.82 \pm 0.00$ & $0.90 \pm 0.37$ & $0.98 \pm 0.79$ & $0.08 \pm 0.37$ & $0.16 \pm 0.79$ & 0.312 & 0.715 \\
\hline $\mathrm{NL}$ ICAM-1(pg/ml) & $109.7 \pm 138$ & $93.5 \pm 142$ & $85.3 \pm 103$ & $-16.2 \pm 114$ & $-24.4 \pm 74.5$ & 0.409 & 0.398 \\
\hline CRP (mg/L) & $2.0 \pm 2.2$ & $1.9 \pm 2.0$ & $1.6 \pm 1.6$ & $-0.12 \pm 0.24$ & $-0.39 \pm 0.71$ & 0.034 & 0.283 \\
\hline Fibrinogen (g/l) & $3.2 \pm 0.7$ & $3.3 \pm 0.8$ & $3.4 \pm 01.0$ & $0.13 \pm 0.55$ & $0.26 \pm 0.84$ & 0.968 & 0.940 \\
\hline CC16 ( $\mu \mathrm{g} / \mathrm{l})$ & $6.21 \pm 2.23$ & $6.64 \pm 3.44$ & $6.12 \pm 2.32$ & $0.43 \pm 2.50$ & $-0.09 \pm 1.44$ & 0.224 & 0.016 \\
\hline SP-D ( $\mu \mathrm{g} / \mathrm{l})$ & $63.4 \pm 34.0$ & $61.9 \pm 32.7$ & $66.7 \pm 32.8$ & $-1.45 \pm 4.78$ & $3.34 \pm 12.1$ & 0.626 & 0.838 \\
\hline
\end{tabular}

Values are mean \pm standard deviation (SD).

$D E$, diesel exhaust; $F A$, filtered air; $N L$, nasal lavage.

${ }^{\mathrm{a}} \Delta$ after exposure $=$ after exposure - before exposure; $\Delta 20 \mathrm{~h}$ post-exposure $=20 \mathrm{~h}$ post-exposure - before exposure.

concentrations in nasal lavage $[41,42]$, but concentrations of IL-6, IL-8 were not altered by intranasal challenge with $\mathrm{DE}$ alone in healthy volunteers [43].

CC16 is an anti-inflammatory protein secreted by the Clara cells located in the bronchioli [44], and the transfer to serum is increased when the permeability of the lung epithelial barrier is compromised [45]. Two chamber studies found increased serum CC16 after exposure to wood smoke at PM mass concentrations similar to those in the present study $[46,47]$. CC16 levels were, however, seldom reported at DE exposure in previous chamber studies. In this study, the slight increase of serum CC16 immediately after DE exposure was not statistically significant and levels returned to baseline at $20 \mathrm{~h}$ post-exposure. The reason for the increase in serum CC16 the morning after FA exposure is unclear.

DE exposure, at the moderate levels used in this study, induced a systemic inflammatory response in peripheral blood. Previous experimental studies showed white cell and proinflammatory cytokines changes in bronchoalveolar lavage and bronchial biopsies, but rarely in peripheral blood. Total leukocyte counts were higher after $3 \mathrm{~h}$ exposure to both DE and FA in the afternoon than before exposure in the morning, which reflects the normal circadian variation [48]. However, the total leukocyte counts remained increased at $20 \mathrm{~h}$ post-exposure after DE exposure, but not after FA exposure, which suggests a slight systemic cellular inflammatory response after exposed to DE. Changes in pro-inflammatory cytokines in peripheral blood were also identified. The trend towards an increase of serum IL-6 $(\mathrm{p}=0.07)$ after DE exposure at $20 \mathrm{~h}$ post-exposure, which was also observed by Tornqvist et al. [49], may represent a pro-inflammatory systemic response. However, consistent with other controlled DE chamber studies performed in either healthy volunteers $[50,51]$ or individuals with chronic obstructive pulmonary 
disease [52], we did not find a DE-associated increase in CRP. The follow-up time in the present study perhaps has been too short to detect a change in CRP.

\section{Conclusion}

In summary, this study shows that short-term exposure to $\mathrm{DE}$ at $300 \mu \mathrm{g} / \mathrm{m}^{3}$ can cause irritation in upper airways, along with a temporary decline in PEF in healthy subjects, after only $75 \mathrm{~min}$ into exposure. Additionally, the increase in leukocyte cell counts in peripheral blood indicates that these levels of DE exposure also cause a systemic inflammatory response.

\begin{abstract}
Abbreviations
DE: Diesel exhaust; PM: Particulate matter; PEF: Peak expiratory flow: FA: Filtered air; VAS: Visual analogue scale; MWPFM: Mini-Wright Peak Flow Meter; FVC: Forced vital capacity; FEV 1 : Forced expiratory volume in one second; MCA $_{1}$ : Minimal cross-sectional area between 0-22 mm; $\mathrm{MCA}_{2}$ : Minimal cross-sectional area between $22-45 \mathrm{~mm}$; CRP: $\mathrm{C}$ reactive protein; IL: Interleukin; ICAM: Intercellular adhesion molecule; TNF: Tumor necrosis factor; CC16: Clara cell protein; SP-D: Surfactant protein D; OR: Odds ratio; ACGIH: American Conference of Governmental Industrial Hygienists; TLVs: Threshold Limit Values; TWAs: 8-hour time-weighted averages.
\end{abstract}

\section{Competing interests}

The authors declare that they have no competing financial interests

\section{Authors' contributions}

AW, AG and MA designed the project and performed the chamber exposure. AG and AW generated the aerosol. AW provided exposure characteristics. JN and MA were responsible for the medical examinations. BJ and MK measured biomarkers. YX, LB, AA, MK and MA analyzed the data and interpreted the results. The manuscript was written by $Y X$ and revised critically by LB and MA. All authors read, corrected and approved the manuscript.

\section{Acknowledgements}

We would like to thank Ulla Andersson, Eva Assarsson, Margareta Berglund, Mats Bohgard, Jonas Brunskog, Anna-Therese Gunnskog, Inger Hagerman, Patrik Nilsson, Joakim Pagels, Torben Poulsen, Jenny Rissler, Leo Stockfelt, Gerd Sällsten, Gertrud Wohlfart and Kai Österberg for invaluable assistance in conducting this study. We also would like to express our gratitude to the volunteers who participated in the investigation. Anders Blomberg gave valuable comments to a previous version of the manuscript.

The DINO study was financed by the Swedish Research Council FORMAS, the Swedish Council for Working Life and Social Research (FAS), the Sound Environment Center at Lund University and Vinnova Swedish Governmental Agency for Innovation, and was performed within the framework of Metalund, the Centre for Medicine and Technology for Working Life and Society.

\section{Author details}

'Division of Occupational and Environmental Medicine, Lund University, SE 221-85 Lund, Sweden. ${ }^{2}$ Department of Occupational and Environmental Medicine, Sahlgrenska University Hospital and Academy, University of Gothenburg, Box 414, SE-405 30 Gothenburg, Sweden. ${ }^{3}$ Department of Occupational and Environmental Medicine, Division of Laboratory Medicine, Region Skåne, Sweden. ${ }^{4}$ Ergonomics and Aerosol Technology, Lund University, Box 118, SE-221 00 Lund, Sweden.

Received: 21 December 2012 Accepted: 24 July 2013

Published: 9 December 2013

\section{References}

1. de-Kok TM, Driece HA, Hogervorst JG, Briede JJ: Toxicological assessment of ambient and traffic-related particulate matter: a review of recent studies. Mutat Res 2006, 613:103-122.
2. Pope CA 3rd, Dockery DW: Health effects of fine particulate air pollution: lines that connect. J Air Waste Manag Assoc 2006, 56:709-742.

3. Brook RD, Rajagopalan S, Pope CA 3rd, Brook JR, Bhatnagar A, Diez-Roux AV Holquin F, Hong Y, Luepker RV, Mittleman MA, Peters A, Siscovick D, Smith SC Jr, Whitsel L, Kaufman JD: Particulate matter air pollution and cardiovascular disease: an update to the scientific statement from the american heart association. Circulation 2010, 121:2331-2378.

4. Gan WQ, Fitzgerald JM, Carlsten C, Sadatsafavi M, Brauer M: Associations of ambient air pollution with chronic obstructive pulmonary disease hospitalization and mortality. Am J Respir Crit Care Med 2013, 187(7):721-7.

5. Faustini A, Stafoggia M, Colais P, Berti G, Bisanti L, Cadum E, Cernigliaro A, Mallone S, Scarnato C, Forastiere F: Air pollution and multiple acute respiratory outcomes. Eur Respir J 2013. Epub ahead of print].

6. World Health Orgnization: Burden of disease associated with urban outdoor air pollution for 2008; 2008. http://www.who.int/phe/health_topics/ outdoorair/databases/burden_disease/en/index.html.

7. U.S. Environmental Protection Agency: Health assessment document for diesel engine exhaust. Report EPAV600/8-90/057F. Washington, DC: U.S. Environmental Protection Agency; 2002.

8. U.S. Environmental Protection Agency: Air quality criteria for particulatematter (October 2004) Volume I. Report EPA 600/p-99/002AF. Washington, DC: U.S. Environmental Protection Agency; 2004.

9. Gauderman WJ, Vora H, McConnell R, Berhane K, Gilliland F, Thomas D, Lurmann F, Avol E, Kunzli N, Jerrett M, Peters J: Effect of exposure to traffic on lung development from 10 to 18 years of age: a cohort study. Lancet 2007, 369:571-577.

10. Ulvestad B, Bakke B, Eduard W, Kongerud J, Lund MB: Cumulative exposure to dust causes accelerated decline in lung function in tunnel workers. Occup Environ Med 2001, 58:663-669.

11. Riedl M, Diaz-Sanchez D: Biology of diesel exhaust effects on respiratory function. J Allergy Clin Immunol 2005, 115:221-228. quiz 229.

12. Hart JE, Laden F, Eisen EA, Smith TJ, Garshick E: Chronic obstructive pulmonary disease mortality in railroad workers. Occup Environ Med 2009, 66:221-226.

13. Hart JE, Eisen EA, Laden F: Occupational diesel exhaust exposure as a risk factor for chronic obstructive pulmonary disease. Curr Opin Pulm Med 2012, 18:151-154.

14. Pedeli X, Hoek G, Katsouyanni K: Risk assessment of diesel exhaust and lung cancer: combining human and animal studies after adjustment for biases in epidemiological studies. Environ Health 2011, 10:30.

15. Olsson AC, Gustavsson P, Kromhout $H$, Peters $S$, Vermeulen R, Bruske Pesch B, Siemiatycki J, Pintos J, Bruning T, Cassidy A, Wichmann HE, Consonni D, Landi MT, Caporaso N, Plato N, Merletti F, Mirabelli D, Richiardi L, Jockel KH, Ahrens W, Pohlabeln H, Lissowska J, Szeszenia-Dabrowska N, Zaridze D, Stucker I, Benhamou S, Bencko V, Foretova L, Janout V, Rudnai P, Fabianova E, Dumitru RS, Gross IM, Kendzia B, Forastiere F, Bueno-de-Mesquita B, Brennan P, Boffetta P, Straif K: Exposure to diesel motor exhaust and lung cancer risk in a pooled analysis from case-control studies in Europe and Canada. Am J Respir Crit Care Med 2011, 183:941-948.

16. International Agency for Research on Cancer: Carcinogenicity of diesel-engine and gasoline-engine exhausts and some nitroarenes. Lyon: IARC Monographs on the Evaluation of Carcinogenic Risks to Humans Vol 125; 2012.

17. Sehlstedt M, Behndig AF, Boman C, Blomberg A, Sandstrom T, Pourazar J: Airway inflammatory response to diesel exhaust generated at urban cycle running conditions. Inhal Toxicol 2010, 22:1144-1150.

18. Pourazar J, Frew AJ, Blomberg A, Helleday R, Kelly FJ, Wilson S, Sandstrom T: Diesel exhaust exposure enhances the expression of il-13 in the bronchial epithelium of healthy subjects. Respir Med 2004, 98:821-825.

19. Salvi S, Blomberg A, Rudell B, Kelly F, Sandstrom T, Holgate ST, Frew A: Acute inflammatory responses in the airways and peripheral blood after short-term exposure to diesel exhaust in healthy human volunteers. Am J Respir Crit Care Med 1999, 159:702-709.

20. Stenfors N, Nordenhall C, Salvi SS, Mudway I, Soderberg M, Blomberg A, Helleday R, Levin JO, Holgate ST, Kelly FJ, Frew AJ, Sandstrom T: Different airway inflammatory responses in asthmatic and healthy humans exposed to diesel. Eur Respir J 2004, 23:82-86.

21. Behndig AF, Mudway IS, Brown JL, Stenfors N, Helleday R, Duggan ST, Wilson SJ, Boman C, Cassee FR, Frew AJ, Kelly FJ, Sandstrom T, Blomberg A: Airway antioxidant and inflammatory responses to diesel exhaust exposure in healthy humans. Eur Respir J 2006, 27:359-365.

22. Salvi SS, Nordenhall C, Blomberg A, Rudell B, Pourazar J, Kelly FJ, Wilson S, Sandstrom T, Holgate ST, Frew AJ: Acute exposure to diesel exhaust 
increases il-8 and gro-alpha production in healthy human airways. Am J Respir Crit Care Med 2000, 161:550-557.

23. Rudell B, Ledin MC, Hammarstrom U, Stjernberg N, Lundback B, Sandstrom $\mathrm{T}$ : Effects on symptoms and lung function in humans experimentally exposed to diesel exhaust. Occup Environ Med 1996, 53:658-662.

24. Nordenhall C, Pourazar J, Ledin MC, Levin JO, Sandstrom T, Adelroth E: Diesel exhaust enhances airway responsiveness in asthmatic subjects. Eur Respir J 2001, 17:909-915.

25. Nightingale JA, Maggs R, Cullinan P, Donnelly LE, Rogers DF, Kinnersley R, Chung KF, Barnes PJ, Ashmore M, Newman-Taylor A: Airway inflammation after controlled exposure to diesel exhaust particulates. Am J Respir Crit Care Med 2000, 162:161-166.

26. Wierzbicka A, Nilsson P, Rissler J, Sällsten G, Xu Y, Pagels J, Albin M, Osterberg K, Strandberg B, Eriksson A, Bohgard M, Bergemalm-Rynell K, Gudmundsson A: Detailed diesel exhaust characteristics including particle surface area and lung deposited dose for better understanding of health effects in human laboratory exposure studies. Atmos Environ 2013, doi: 10.1016/j.atmosenv.2013.11.025

27. Bausewein C, Farquhar M, Booth S, Gysels M, Higginson IJ: Measurement of breathlessness in advanced disease: a systematic review. Respir Med 2007, 101:399-410.

28. Miller MR, Hankinson J, Brusasco V, Burgos F, Casaburi R, Coates A, Crapo R, Enright $P$, van der-Grinten CP, Gustafsson $P$, Jensen $R$, Johnson DC, Macintyre N, McKay R, Navajas D, Pedersen OF, Pellegrino R, Viegi G, Wanger J: Standardisation of spirometry. Eur Respir J 2005, 26:319-338.

29. Hilberg O: Objective measurement of nasal airway dimensions using acoustic rhinometry: Methodological and clinical aspects. Allergy 2002, 57(Suppl 70):5-39.

30. Koren HS, Hatch GE, Graham DE: Nasal lavage as a tool in assessing acute inflammation in response to inhaled pollutants. Toxicology 1990, 60:15-25.

31. Douwes J, Wouters I, Dubbeld H, van-Zwieten L, Steerenberg P, Doekes G, Heederik D: Upper airway inflammation assessed by nasal lavage in compost workers: a relation with bio-aerosol exposure. Am J Ind Med 2000, 37:459-468.

32. Benson M, Strannegard IL, Wennergren G, Strannegard O: Interleukin-5 and interleukin- 8 in relation to eosinophils and neutrophils in nasal fluids from school children with seasonal allergic rhinitis. Pediatr Allergy Immunol 1999, 10:178-185.

33. Behndig AF, Larsson N, Brown JL, Stenfors N, Helleday R, Duggan ST, Dove RE, Wilson SJ, Sandstrom T, Kelly FJ, Mudway IS, Blomberg A: Proinflammatory doses of diesel exhaust in healthy subjects fail to elicit equivalent or augmented airway inflammation in subjects with asthma. Thorax 2011, 66:12-19.

34. Giles LV, Carlsten C, Koehle MS: The effect of pre-exercise diesel exhaust exposure on cycling performance and cardio-respiratory variables. Inhal Toxicol 2012, 24:783-789.

35. Lotz G, Plitzko S, Gierke E, Tittelbach U, Kersten N, Schneider WD: Dose-response relationships between occupational exposure to potash, diesel exhaust and nitrogen oxides and lung function: cross-sectional and longitudinal study in two salt mines. Int Arch Occup Environ Health 2008, 81:1003-1019.

36. American Conference of Governmental Industrial Hygienists: Threshold limit values for chemical substance and physical agents and biological indices for 1995/1996. Cincinnati: American Conference of Governmental Industrial Hygienists; 1996.

37. Rudell B, Sandstrom T, Hammarstrom U, Ledin ML, Horstedt P, Stjernberg N: Evaluation of an exposure setup for studying effects of diesel exhaust in humans. Int Arch Occup Environ Health 1994, 66:77-83.

38. Wilhelmsson B, Holmstrom M: Possible mechanisms of formaldehyde-induced discomfort in the upper airways. Scand J Work Environ Health 1992, 18:403-407.

39. Hauser R, Garcia-Closas M, Kelsey KT, Christiani DC: Variability of nasal lavage polymorphonuclear leukocyte counts in unexposed subjects: its potential utility for epidemiology. Arch Environ Health 1994, 49:267-272.

40. Blomberg A, Sainsbury C, Rudell B, Frew AJ, Holgate ST, Sandstrom T, Kelly FJ: Nasal cavity lining fluid ascorbic acid concentration increases in healthy human volunteers following short term exposure to diesel exhaust. Free Radic Res 1998, 28:59-67.

41. Diaz-Sanchez D, Penichet-Garcia M, Saxon A: Diesel exhaust particles directly induce activated mast cells to degranulate and increase histamine levels and symptom severity. J Allergy Clin Immun 2000, 106:1140-1146.

42. Bastain TM, Gilliland FD, Li YF, Saxon A, Diaz-Sanchez D: Intraindividual reproducibility of nasal allergic responses to diesel exhaust particles indicates a susceptible phenotype. Clin Immunol 2003, 109:130-136.
43. Kongerud J, Madden MC, Hazucha M, Peden D: Nasal responses in asthmatic and nonasthmatic subjects following exposure to diesel exhaust particles. Inhal Toxicol 2006, 18:589-594.

44. Broeckaert F, Clippe A, Knoops B, Hermans C, Bernard A: Clara cell secretory protein (cc16): features as a peripheral lung biomarker. Ann N Y Acad Sci 2000, 923:68-77.

45. Barregard L, Sallsten G, Gustafson P, Andersson L, Johansson L, Basu S, Stigendal L: Experimental exposure to wood-smoke particles in healthy humans: effects on markers of inflammation, coagulation, and lipid peroxidation. Inhal Toxicol 2006, 18:845-853.

46. Stockfelt L, Sallsten G, Olin AC, Almerud P, Samuelsson L, Johannesson S, Molnar P, Strandberg B, Almstrand AC, Bergemalm-Rynell K: Effects on airways of short-term exposure to two kinds of wood smoke in a chamber study of healthy humans. Inhal Toxicol 2012, 24:47-59.

47. Barregard L, Sällsten G, Andersson L, Almstrand AC, Gustafson P, Andersson $\mathrm{M}$, Olin AC: Experimental exposure to wood smoke: effects on airway inflammation and oxidative stress. Occup Environ Med 2008, 65:319.

48. Bertouch JV, Roberts-Thomson PJ, Bradley J: Diurnal variation of lymphocyte subsets identified by monoclonal antibodies. Br Med J (Clin Res Ed) 1983, 286:1171-1172

49. Tornqvist H, Mills NL, Gonzalez M, Miller MR, Robinson SD, Megson IL, MacNee W, Donaldson K, Soderberg S, Newby DE: Persistent endothelial dysfunction following diesel exhaust inhalation in man. Am J Respir Crit Care Med 2007, 176:395-400

50. Mills NL, Tornqvist H, Robinson SD, Gonzalez M, Darnley K, MacNee W, Boon NA, Donaldson K, Blomberg A, Sandstrom T, Newby DE: Diesel exhaust inhalation causes vascular dysfunction and impaired endogenous fibrinolysis. Circulation 2005, 112:3930-3936.

51. Carlsten C, Kaufman JD, Peretz A, Trenga CA, Sheppard L, Sullivan JH: Coagulation markers in healthy human subjects exposed to diesel exhaust. Thromb Res 2007, 120:849-855.

52. Blomberg A, Tornqvist $H$, Desmyter $L$, Deneys V, Hermans C: Exposure to diesel exhaust nanoparticles does not induce blood hypercoagulability in an at-risk population. J Thromb Haemost: JTH 2005, 3:2103-2105.

doi:10.1186/1743-8977-10-60

Cite this article as: Xu et al.: Effects of diesel exposure on lung function and inflammation biomarkers from airway and peripheral blood of healthy volunteers in a chamber study. Particle and Fibre Toxicology 2013 10:60.

\section{Submit your next manuscript to BioMed Central and take full advantage of:}

- Convenient online submission

- Thorough peer review

- No space constraints or color figure charges

- Immediate publication on acceptance

- Inclusion in PubMed, CAS, Scopus and Google Scholar

- Research which is freely available for redistribution 